\title{
EFFECT OF CALCIUM SALTS ON POSTHARVEST FUNGAL PATHOGENS IN VITRO
}

\author{
STEFAN STOŠIĆ ${ }^{1}$, SAŠA STOJANOVIĆ2, ANJA MILOSAVLJEVIĆ ${ }^{2}$, \\ ERIKA PFAF DOLOVAC ${ }^{2}$, SVETLANA ŽIVKOVIĆ ${ }^{2}$ \\ ${ }^{1}$ Scholar of Ministry of Education, Science and Technological Development \\ of the Republic of Serbia \\ ${ }^{2}$ Institute for Plant Protection and Environment, Belgrade, Serbia \\ e-mail:stefan.stosic@gmail.com
}

\section{SUMMARY}

\section{INTRODUCTION}

Synthetic fungicides have been routinely used to control postharvest diseases. However, the development of fungicide resistance and an increasing environmental concern over fungicide residues in food have stimulated to find alternative means for controlling postharvest decay (Holmes and Eckert, 1999). Among alternatives to synthetic chemicals, several inorganic salts and organic, lipophilic acids and their salts have shown increasing evidence of efficacy in controlling plant pathogens. Many of these salts are widely used in industry as preservatives and antimicrobials (Russell and Gould, 1991) and have shown some advantages for utilization as postharvest chemicals, such as a broad-spectrum antimicrobial activity with low mammalian toxicity (Olivier et al., 1998), and biocompatibility (Horst et al., 1992).

Several studies have been undertaken in re- cent years identifying the fungicidal properties of many different antimicrobial salts. Sodium carbonate, sodium bicarbonate, potassium carbonate, potassium bicarbonate, ammonium bicarbonate, and potassium silicate have been tested for inhibition of fungal pathogens on fruits, vegetables, field crops and ornamentals. These salts demonstrated in vitro and/or in vivo inhibition of Fusarium tricinctum, F. graminearum, F. sporotrichioides, Aspergillus ochraceus, A. flavus, A. niger, P. griseofulvum, $P$. notatum, P. digitatum, P. expansum, Botrytis cinerea, Helminthosporium solani, C. acutatum, and C. gloeosporioides (DePasquale et al., 1990; Olivier et al., 1998; Smilanick et al., 1999; Karabulut et al., 2001; Hervieux et al., 2002; Conway et al., 2007; Hasan et al., 2012). Sorbic and propionic acids and their salts are used as preserving additives in milled corn and have been tested for the suppression of mycotoxins and storage molds (Rusul et al., 1987; Buazzi and Marth, 1991). 
Calcium is a key plant nutrient that has a significant role in cell functions, including reducing softening and senescence of fruits (Conway et al., 1991). Many disorders of crops, such as bitter pit in apple, cork spot in pear, and blossom end rot in tomato that are caused by calcium deficiency could be reduced by calcium spraying (Kader, 2002). The most common form of calcium supplement is calcium chloride, however, many proprietary products containing calcium in other forms, or combined with other nutrients are available.

Few studies have examined the potential role of calcium supplementation in the postharvest period for reducing decay (Conway et al., 1994). Saftner et al. (1997) reported that postharvest calcium treatment of apples provided broad-spectrum protection against $P$. expansum and B. cinerea, and Alternaria rot of the apple cultivar Nittany was effectively managed with preand postharvest calcium applications (Biggs et al., 1993; Biggs et al., 2000; Maouni et al., 2007). Biggs (1999) examined the effects of calcium salt solutions on two Colletotrichum species originated from apple fruits. The results verified the effect of calcium salts on reduction of disease severity, expressed as lesion diameter. Also, there are few reports about effects of calcium salts on infection of tropical fruits by Colletotrichum spp. (Chillet et al., 2000; Mahmud et al., 2008; Madani et al., 2014). The ability of calcium to reduce the development of postharvest diseases of fruit has been attributed mainly to the formation of calcium cross-linkages in the cell wall, resulting in decreased effectiveness of cell wall-macerating enzymes secreted by the pathogen (Conway et al., 1988).

Postharvest fungal decay may cause significant losses to the apple production and storage in Serbia. Therefore, the present study was conducted in order to examine and compare the effects of two calcium salts on in vitro growth, spore germination and germ tube elongation of the postharvest pathogens C. acutatum, C. gloeosporioides, A. alternata, and P. expansum.

\section{MATERIAL AND METHODS}

\section{Pathogens}

C. acutatum, C. gloeosporioides, A. alternata, and P. expansum were isolated from decayed apple fruits. The fungi were maintained on potato dextrose agar (PDA) at $4^{\circ} \mathrm{C}$.

\section{Effect of calcium salts on mycelial growth in vitro}

Pure calcium salts used in this study were calcium chloride and calcium hydroxide. Salts were prepared in sterile deionzed distilled water, added to autoclaved warm $\left(\sim 50^{\circ} \mathrm{C}\right)$ PDA to provide a final concentration of $1,1.5$, and $2 \%(\mathrm{w} / \mathrm{v})$. An agar disc $(\emptyset 5 \mathrm{~mm})$ taken from an active colony of tested fungal pathogens was placed in the center of each of three replicate Petri plates. PDA not supplemented with calcium salts served as a control. The all Petri plates were incubated at $25^{\circ} \mathrm{C}$, and growth was assessed after 7 days.

\section{Effect of calcium salts on spore germination and germ tube elongation in vitro}

Spore suspensions of all tested fungal pathogens were obtained from 2- week-old cultures incubated at $25^{\circ} \mathrm{C}$ by flooding the cultures with sterile-distilled water containing $0.05 \%(\mathrm{v} / \mathrm{v})$ Tween 80 , and filtered through four layers of sterilized cheesecloth. Spore concentration was determined with a hemacytometer, and adjusted to $1 \times 10^{6}$ conidia $/ \mathrm{ml}$. Aliquots of $100 \mu \mathrm{l}$ of the pathogen suspension were transferred to glass tubes containing $5 \mathrm{ml}$ potato dextrose broth (PDB), and then the tested chemicals were added to each tube to achieve the proposed concentration. All tubes were put on a rotary shaker at $110 \mathrm{rpm}$ at $25^{\circ} \mathrm{C}$. After $18 \mathrm{~h}$ incubation, 100 spores of pathogens were measured for germination rate. Spores were considered germinated when germ tube length was equal to or greater than spore length.

The efficacy of each treatment was calculated according to the following formula: $\mathrm{R}(\%)=\mathrm{K}-\mathrm{T} / \mathrm{K} \mathrm{x}$ 100 , where $\mathrm{R}$ is reduction, $\mathrm{K}$ is spore germination or germ tube growth in control medium, and $\mathrm{T}$ is spore germination or germ tube growth in a medium with tested calcium salts.

\section{Statistical Analysis}

All treatments consisted of three replicates, and experiments were repeated twice. The data were analyzed by analysis of variance (ANOVA). Mean values were compared using Duncan's multiple range test, and significance was evaluated at $\mathrm{P}<0.05$.

\section{RESULTS AND DISCUSSION}

Calcium chloride and calcium hydroxide at $1 \%$ stimulated mycelial growth of C. acutatum 


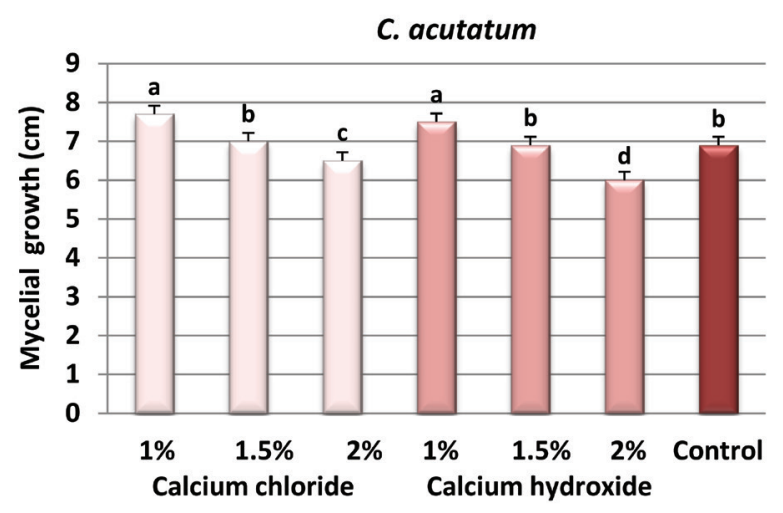

Fig. 1. Effect of calcium salts on mycelial growth of C. acutatum. Means with the same letter are not significantly different according to the Duncan's multiple range test $(\mathrm{P}<0.05)$.

Sl. 1. Efekat kalcijumovih soli na porast micelije $C$. acutatum. Vrednosti sa istim slovom nisu statistički značajno različite na osnovu Duncan's multiple range testa $(\mathrm{P}<0.05)$.

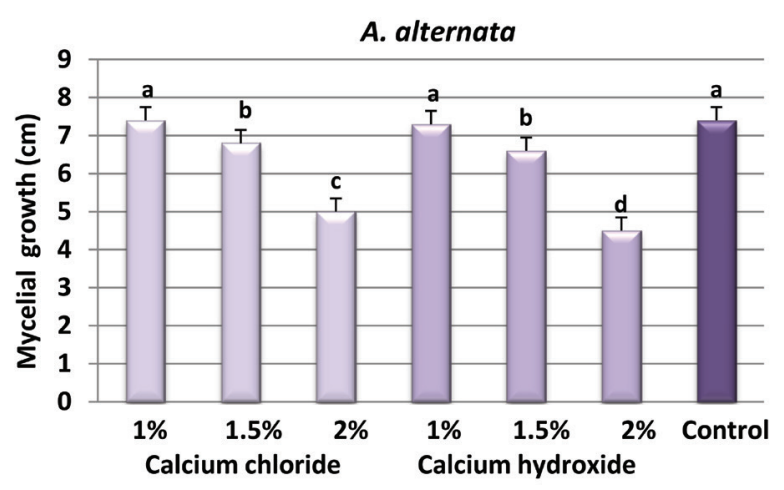

Fig. 3. Effect of calcium salts on mycelial growth of A. alternata. Means with the same letter are not significantly different according to the Duncan's multiple range test $(\mathrm{P}<0.05)$.

Sl. 3. Efekat kalcijumovih soli na porast micelije A. alternata. Vrednosti sa istim slovom nisu statistički značajno različite na osnovu Duncan's multiple range testa $(\mathrm{P}<0.05)$.

and C. gloeosporioides relative to the control. The mycelial growth at $1.5 \%$ calcium salts was similar compared to the control (Fig. 1-2). Also, no reduction in growth was observed when A. alternata and P. expansum were cultured on PDA supplemented with $1 \%$ calcium chloride and calcium hydroxide (Fig. 3-4). In this experiment, only the calcium salts at $2 \%$ concentration reduced mycelial growth of all tested pathogens, relative to the control. Our results are in agreement with those of other researchers who demonstrated that the fungal isolates grew similarly or stimulated in the presence of calcium

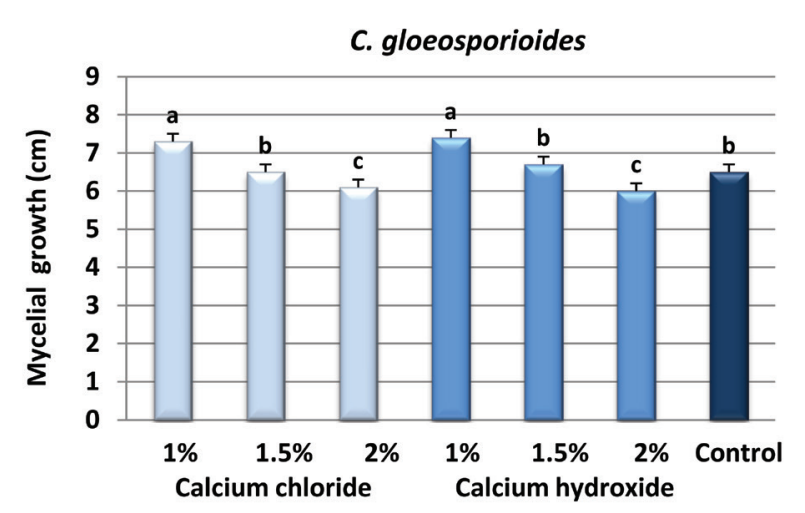

Fig. 2. Effect of calcium salts on mycelial growth of C. gloeosporioides. Means with the same letter are not significantly different according to the Duncan's multiple range test $(\mathrm{P}<0.05)$.

Sl. 2. Efekat kalcijumovih soli na porast micelije C. gloeosporioides. Vrednosti sa istim slovom nisu statistički značajno različite na osnovu Duncan's multiple range testa $(\mathrm{P}<0.05)$.

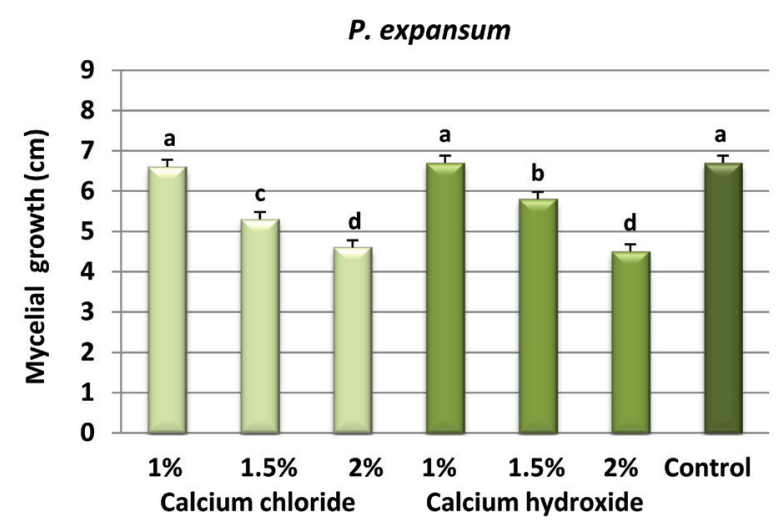

Fig. 4. Effect of calcium salts on mycelial growth of $P$. expansum. Means with the same letter are not significantly different according to the Duncan's multiple range test $(\mathrm{P}<0.05)$.

Sl. 4. Efekat kalcijumovih soli na porast micelije $P$. expansum. Vrednosti sa istim slovom nisu statistički značajno različite na osnovu Duncan's multiple range testa $(\mathrm{P}<0.05)$.

salts compared to the control (Biggs, 2004; Madani et al., 2014). Tian et al. (2002) recorded that calcium chloride at $2 \%$ inhibited the growth of R. stolonifer, although calcium chloride was tolerated by A. alternata and $P$. expansum in vitro where their growth was highly affected only at $6 \%$ concentration (Maouni et al., 2007). Calcium salts also have been shown to reduce mycelial growth in vitro and reduce incidence and severity of infection of peach fruits and shoots by Monilinia fructicola and Leucostoma persoonii, respectively (Biggs and Peterson, 1990; Biggs et al., 1997). 
Table 1. Effect of calcium salts on in vitro conidial germination and germ tube growth of postharvest fungal pathogens.

Tabela 1. In vitro efekat kalcijumovih soli na klijavost konidija i porast klicine cevi skladišnih gljivičnih patogena.

\begin{tabular}{|c|c|c|c|c|c|c|c|c|c|}
\hline \multirow{3}{*}{$\begin{array}{l}\text { Treatment } \\
\text { Tretman }\end{array}$} & \multirow{3}{*}{ Conc. $\%$} & \multicolumn{8}{|c|}{$\begin{array}{l}\text { Pathogen } \\
\text { Patogen }\end{array}$} \\
\hline & & \multicolumn{2}{|c|}{$\begin{array}{c}C . \\
\text { acutatum }\end{array}$} & \multicolumn{2}{|c|}{$\begin{array}{c}C . \\
\text { gloeosporioides }\end{array}$} & \multicolumn{2}{|c|}{$\begin{array}{c}\text { A. } \\
\text { alternata }\end{array}$} & \multicolumn{2}{|c|}{$\begin{array}{c}P . \\
\text { expansum }\end{array}$} \\
\hline & & $\mathrm{RSG}^{*}(\%)$ & $\begin{array}{c}\text { RGTG** } \\
(\%)\end{array}$ & RSG (\%) & $\begin{array}{l}\text { RGTG } \\
(\%)\end{array}$ & RSG (\%) & $\begin{array}{c}\text { RGTG } \\
(\%)\end{array}$ & RSG (\%) & $\begin{array}{c}\text { RGTG } \\
(\%)\end{array}$ \\
\hline \multirow{3}{*}{$\begin{array}{l}\text { Calcium } \\
\text { chloride }\end{array}$} & 1 & $16.8 \mathrm{~d} * * *$ & $35.3 \mathrm{~d}$ & $16.3 \mathrm{c}$ & $29.4 d$ & $21.1 \mathrm{~d}$ & $38.9 \mathrm{~d}$ & $31.5 \mathrm{~d}$ & $46.6 \mathrm{c}$ \\
\hline & 1.5 & $24.3 \mathrm{c}$ & $47.4 \mathrm{c}$ & $23.4 b$ & $41.5 \mathrm{c}$ & $38.8 \mathrm{c}$ & $49.6 \mathrm{c}$ & $44.3 \mathrm{c}$ & $59.3 b$ \\
\hline & 2 & $38.5 \mathrm{a}$ & $57.1 \mathrm{a}$ & $38.2 \mathrm{a}$ & $53.1 \mathrm{a}$ & $52.7 \mathrm{a}$ & $63.8 \mathrm{a}$ & $61.1 \mathrm{a}$ & $70.5 \mathrm{a}$ \\
\hline \multirow{3}{*}{$\begin{array}{l}\text { Calcium } \\
\text { hydroxide }\end{array}$} & 1 & $16.2 \mathrm{~d}$ & $34.1 \mathrm{~d}$ & $13.3 \mathrm{~d}$ & $30.4 d$ & $22.5 \mathrm{~d}$ & $37.5 \mathrm{~d}$ & $32.8 \mathrm{~d}$ & $47.6 \mathrm{c}$ \\
\hline & 1.5 & $23.6 \mathrm{c}$ & $46.1 \mathrm{c}$ & $24.7 b$ & $40.9 \mathrm{c}$ & $38.1 \mathrm{c}$ & $47.5 \mathrm{c}$ & $44.6 \mathrm{c}$ & $59.8 \mathrm{~b}$ \\
\hline & 2 & $32.8 \mathrm{~b}$ & $53.3 \mathrm{~b}$ & $37.9 \mathrm{a}$ & $48.7 \mathrm{~b}$ & $47.4 \mathrm{~b}$ & $59.8 \mathrm{~b}$ & $57.8 \mathrm{~b}$ & $70.2 \mathrm{a}$ \\
\hline
\end{tabular}

RSG* $^{*}$ Reduction of spore germination; RGTG** - Reduction of germ tube growth; *** - Means in column followed by the same letter are not significantly different according to the Duncan's multiple range test $(\mathrm{P}<0.05)$.

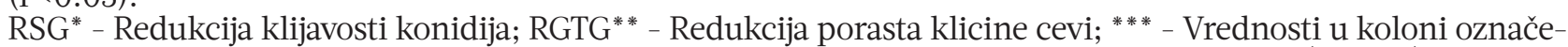
ne istim slovom nisu statistički značajno različite na osnovu Duncan's multiple range testa $(\mathrm{P}<0.05)$.

Conidial germination assay were conducted to test the potential for calcium chloride and calcium hydroxide at different concentrations to inhibit germination of postharvest fungal pathogens. The both of calcium slats were effective in reducing the spore germination and germ tube growth of C. acutatum, C. gloeosporioides, A. alternata and P. expansum. In most cases, in treatments with 1 and $1.5 \%$ calcium salts, inhibition percentage did not exceed $50 \%$. The spore germination of all tested pathogens was decreased significantly on PDA supplemented with $2 \%$ calcium salts (Table 1.). Also, inhibition of germ tube growth was greater, and increases with salts concentration (Table 1.). Our findings are in agreement with those of Eryani-Raqeeb et al. (2009) who demonstrated that high concentration of calcium reduced spore germination of the papaya anthracnose pathogen. Droby et al. (1997) observed inhibition of spore germination and germ tube elongation of $P$. digitatum in culture, as well as inhibition of polygalacturonase activity. Wisniewski et al. (1995) have indicated that calcium chloride reduced germination and germ tube elongation of $B$. cinerea and $P$. expansum in vitro. Increasing concentrations of calcium chloride $(25-175 \mathrm{mM})$ resulted in decreased spore germination and germ tube growth of both pathogens, but the greatest effect was observed in the case of B. cinerea.

Reduced spore germination shows that the pathogen may be more sensitive to calcium at the conidial stage relative to the mycelial growth stage.
The mechanisms by which calcium salts inhibited fungal spore germination and germ tube elongation are not known. One hypothesis is that high concentration of extracellular calcium may increase calcium in the cytosol to toxic levels. With a minimum level of calcium ion concentration being necessary for normal cell growth, any limitation in regulation of intracellular calcium level may result in reduced organism development (Droby et al., 1997). Calcium ions may reduce the incidence of fungal infection by directly inhibiting fungal growth and by inhibiting cell wall-degrading enzymes produced by the pathogens. These effects were probably due the toxicity of higher concentration of calcium on pathogens by affecting the osmotic balance in the fungal cells and inhibition of pectinolytic enzymes (Miceli et al., 1999).

Several studies have shown that calcium salts may have potential as environmentally compatible, nontoxic fungicides for controlling postharvest pathogens. Our results support these findings by showing that calcium chloride and calcium hydroxide restrict in vitro conidial germination and germ tube growth of C. acutatum, C. gloeosporioides, A. alternata, and P. expansum.

\section{ACKNOWLEDGMENT}

This study was supported by the Ministry of Education, Science and Technological Development of the Republic of Serbia, Project TR 31018. 


\section{REFERENCES}

Biggs, A. R., and Peterson, C. A. (1990): Effect of chemical applications to peach bark wounds on accumulation of lignin and suberin and susceptibility to Leucostoma persoonii. Phytopathology, 80: 861-865.

Biggs, A. R., Ingle, M., Solihati, W. D. (1993): Control of Alternaria infection of fruit of apple cultivar Nittany with calcium chloride and fungicides. Plant Disease, 77: 976-980.

Biggs, A.R., El-Kholi, M.M., El-Neshawy, S., Nickerson, R. (1997): Effects of calcium salts on growth, polygalacturonase activity, and infection of peach fruit by Monilinia fruticola. Plant Disease, 81: 399-403.

Biggs, A.R. (1999): Effects of calcium salts on apple bitter rot caused by two Colletotrichum species. Plant Disease, 83: 1001-1005.

Biggs, A. R., Hogmire, H. W., Collins, A. R. (2000): Assessment of an alternative IPM program for the production of apples for processing. Plant Disease, 84: 1140-1146.

Biggs, A.R. (2004): Effect of inoculum concentration and calcium salts on infection of apple fruit by Botryosphaeria dothidea. Plant Disease, 88: 147-151.

Buazzi, M. M., and Marth, E. H. (1991): Mechanisms of the inhibition of Listeria monocytogenes by potassium sorbate. Food Microbiol., 8: 249-256.

Conway, W. S., Gross, K. C., Boyer, C. D., Sams, C. E. (1988): Inhibition of Penicillium expansum polygalacturonase activity by increased apple cell wall calcium. Phytopathology, 78: 1052-1055.

Conway, W.S., Sams, C.E., Abbott, J.A., Bruton, B.D. (1991): Postharvest calcium treatment of apple fruit to provide broad-spectrum protection against postharvest pathogens. Plant Disease, 75: 620-622.

Conway, W. S., Sams, C. E., Brown, G. A., Beavers, W. B., Tobias, R. B., Kennedy, L. S. (1994): Pilot test for the commercial use of postharvest pressure infiltration of calcium into apples to maintain fruit quality in storage. HortTechnology, 4: 239-243.

Conway, W.S., Leverentz, B., Janisiewicz, W.J., Blodgett, A.B., Saftner, R.A., Camp, M.J. (2007): Integrating heat treatment, biocontrol and sodium bicarbonate to reduce postharvest decay of apple caused by Colletotrichum acutatum and Penicillium expansum. Postharvest Biology and Technology, 34: 11-20.

Chillet, M., de Lapeyre de Ballaire, L., Dorel, M., Joas, J., Dubois, C., Marchal, J., Perrier, X. (2000): Evidence for the variation in susceptibility of bananas to wound anthracnose due to Colletotrichum musae and the influence of edaphic conditions. Scientia Horticulture, 86(1): 33-47.

DePasquale, D. A., El-Nabarawy, A., Rosen, J. D., Montville, T. J. (1990): Ammonium bicarbonate inhibition of mycotoxigenic fungi and spoilage yeasts. J. Food Prot., 53: 324-328.

Droby, S., Wisniewski, M. E., Cohen, L., Weiss, B., Touitou, D., Eilam, Y., Chalutz, E. (1997): Influence of $\mathrm{CaCl}_{2}$ on Penicillium digitatum, grapefruit peel tissue, and biocontrol activity of Pichia guilliermondii. Phytopathology, 87: 310-315.

Eryani-Raqeeb, A.A., Mahmud, T.M.M., Syed Omar, S.R., Mohamed Zaki, A.R., Al Eryani, A.R. (2009): Effects of calcium and chitosan treatments on controlling anthracnose and postharvest quality of papaya (Carica papaya L.). Int. J. Agric. Res. 4: 53-68.

Hasan, M.F, Mahmud, T.M.M, Kadir, J., Ding, P., Zaidul, I.S.M. (2012): Sensitivity of Colletotrichum gloeosporioides to sodium bicarbonate on the development of anthracnose in papaya (Carica papaya L. cv. Frangi). Australian Journal of Crop Science, 6(1):17-22. 
Hervieux, V., E.S. Yaganza, J. Arul, Tweddell, R.J. (2002): Effect of organic and inorganic salts on the development of Helminthosporium solani, the causal agent of potato silver scurf. Plant Disease, 86: 1014-1018.

Holmes, G.J., and Eckert, J.W. (1999): Sensitivity of Penicillium digitatum and P. italicum to postharvest citrus fungicides in California. Phytopathology, 89: 716-721.

Horst, R. K., Kawamoto, S. O., Porter, L. L. (1992): Effect of sodium bicarbonate and oils on the control of powdery mildew and black spot of roses. Plant Disease, 76: 247-251.

Kader, A.A. (2002): Post-Harvest Technology of Horticultural Crops. $3^{\text {rd }}$.eds. University of California, Oakland, California. Division of Agriculture and Natural Resources Publication 3311.

Karabulut, O.A., Lurie, S., Droby, S. (2001): Evaluation of the use of sodium bicarbonate, potassium sorbate and yeast antagonists for decreasing postharvest decay of sweet cherries. Postharvest Biology and Technology, 23: 233-236.

Madani, B., Mohamed, M.T.M., Biggs, A.R., Kadir, J., Awang, Y., Tayebimeigooni, A., Shojaei, T.R. (2014): Effect of pre-harvest calcium chloride applications on fruit calcium level and post-harvest anthracnose disease of papaya. Crop Protection, 55: 55-60.

Mahmud, T.M.M., Al Eryani-Raqeeb, A., Syed Omar, S.R., Mohamed Zaki, A.R., Abdul-Rahman, A.E. (2008): Effects of different concentrations and applications of calcium on storage life and physicochemical characteristics of papaya (Carica Papaya L.). American Journal of Agricultural and Biological Science, 3(3): 526-533.

Maouni, A., Lamarti, A., Aidoun, A., Khaddor, M., Badoc, A. (2007): Effect of benzimidazole fungicides and calcium chloride on Alternaria alternata and Penicillium expansum rot during storage of pears. Afric. J. Biotec., 6 (11): 1289-1292.

Miceli, A., Ippolito, A., Linsalata, V., Nigro, F. (1999): Effect of pre-harvest calcium treatment on decay and biochemical changes in table grape during storage. Phytopathol. Mediterr., 38: 48-53.

Olivier, C., Halseth, D. E., Mizubuti, E. S. G., Loria, R. (1998): Postharvest application of organic and inorganic salts for suppression of silver scurf on potato tubers. Plant Disease, 82: 213-217.

Rusul, G., El-Gazzar, F. E., Marth, E. H. (1987): Growth and aflatoxin production by Aspergillus parasiticus NRRL 2999 in the presence of propionic acid and at different initial pH values. J. Food Prot., 50: 909-914.

Russell, N. J., and Gould, G. W. (1991): Food Preservatives. Eds.Blackie and Son, London, U.K.

Saftner, R.A., Conway, W.S., Sams, C.E. (1997): Effects of some polyamine biosynthesis inhibitors and calcium chloride on in vitro growth and decay development in apples caused by Botrytis cinerea and Penicillium expansum. J. Am. Soci. Horti. Sci., 122: 380-385.

Smilanick, J.L., Margosan, D.A., Usall, J., Michael, F. (1999): Control of citrus green mold by carbonate and bicarbonate salts and the influence of commercial post harvest practices on their efficacy. Plant Disease, 83: 139-145.

Tian, S.P., Fan, Q., Xu, Y., Jiang, A.L. (2002): Effects of calcium on biocontrol activity of yeast antagonists against the postharvest fungal pathogen Rhizopus stolonifer. Plant Pathology, 51 (3): 352-358.

Wisniewski, M. E., Droby, S., Chalutz, E., Elam, Y. (1995): Effects of $\mathrm{Ca}^{2+}$ and $\mathrm{Mg}^{2+}$ on Botrytis cinerea and Penicillium expansum in vitro and on the biocontrol activity of Candida oleophila. Plant Pathology, 44: 1016-1024. 


\title{
IN VITRO EFEKAT KALCIJUMOVIH SOLI NA GLJIVIČNE SKLADIŠNE PATOGENE
}

\author{
STEFAN STOŠIĆ ${ }^{1}$, SAŠA STOJANOVIĆ2, ANJA MILOSAVLJEVIĆ ${ }^{2}$, \\ ERIKA PFAF DOLOVAC ${ }^{2}$, SVETLANA ŽIVKOVIĆ ${ }^{2}$
}

\author{
${ }^{1}$ Stipendista Ministarstva prosvete, nauke i tehnološkog razvoja Republike Srbije \\ ${ }^{2}$ Institut za zaštitu bilja i životnu sredinu, Beograd \\ e-mail:stefan.stosic@gmail.com
}

Tokom poslednjih nekoliko godina, više studija je pokazalo da u kontroli gljivičnih skladišnih patogena soli kalcijuma mogu imati potencijal kao ekološki kompatibilni, netoksični fungicidi. Stoga je cilj ovog istraživanja bio da se u in vitro uslovima procene i uporede efekti kalcijum hlorida i kalcijum hidroksida na porast micelije, klijavost konidija i rast klicine cevi gljiva C. acutatum, C. gloeosporioides, A. alternata, i P. expansum. Dobijeni rezultati su pokazali da je u prisustvu 1 i 1,5\% kalcijumovih soli porast izolata gljiva u tretmanima sličan ili povećan u odnosu na kontrolu. Nakon 7 dana inkubacije, redukcija porasta micelije je utvđena samo na PDA podlozi sa 2\% soli kalcijuma. Kalcijum hlorid i kalcijum hidroksid u koncentracijama od 1,5 i 2,0\% značajno smanjuju klijavost konidija i rast klicinih cevi svih ispitivanih izolata gljiva. Rezultati ove studije pokazuju da se testirane soli kalcijuma mogu primeniti kao alternativni tretman u kontroli gljivičnih skladišnih patogena, C. acutatum, C. gloeosporioides, A. alternata i P. expansum.

Ključne reči: gljivični skladišni patogeni, soli kalcijuma, in vitro efekat

(Primljeno: 31.01.2014.)

(Prihvaćeno: 28.02.2014.) 